\title{
Methods for Monitoring Corals and Crustose Coralline Algae to Quantify In-Situ Calcification Rates
}

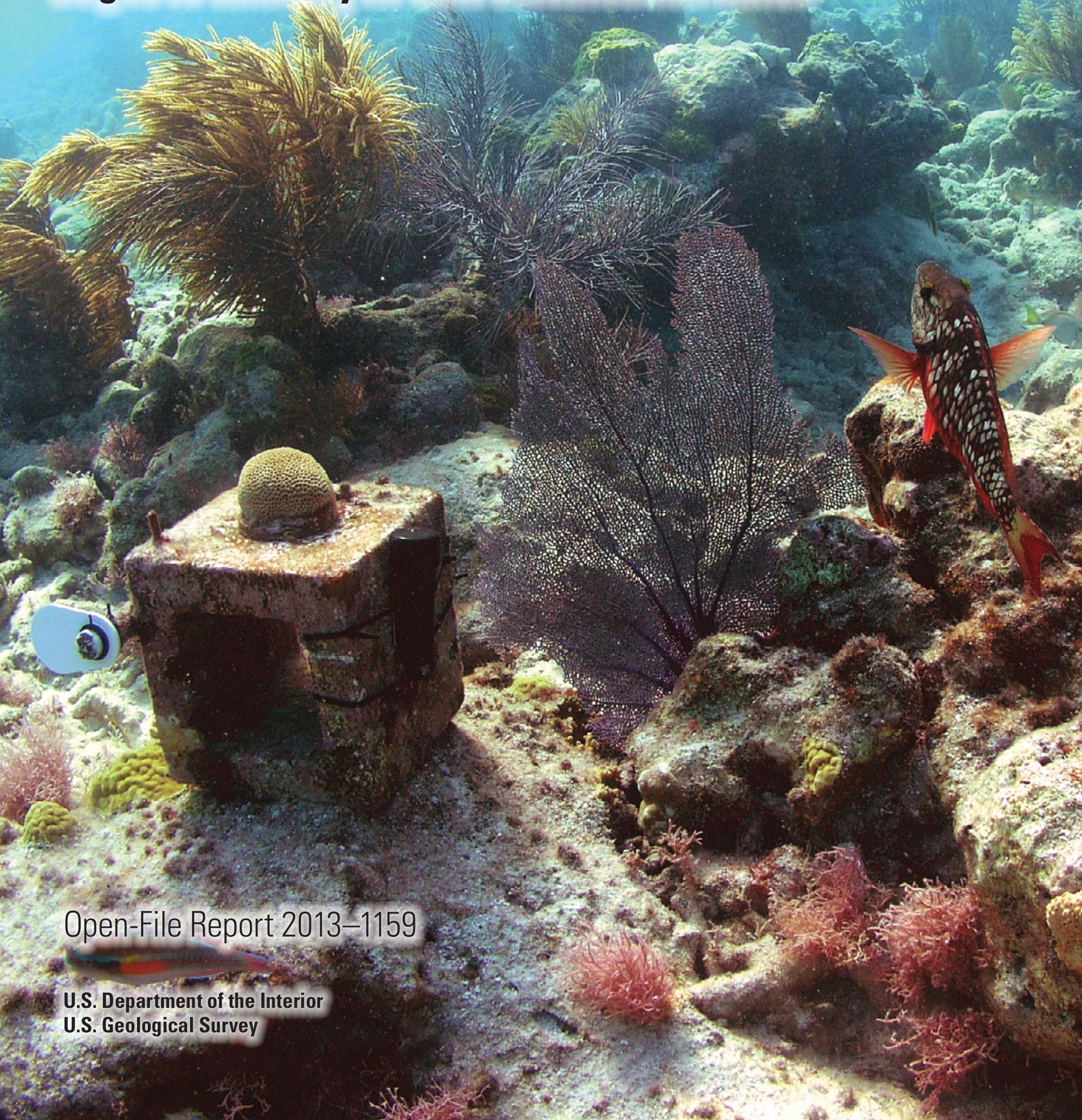


Cover photograph: Calcification-monitoring station, Molasses Reef, Florida Keys National Marine Sanctuary. Photograph by Ilsa Kuffner, November 2012. 


\section{Methods for Monitoring Corals and Crustose Coralline Algae to Quantify In-Situ Calcification Rates}

By Jennifer M. Morrison, Ilsa B. Kuffner, and T. Don Hickey

Open-File Report 2013-1159 


\title{
U.S. Department of the Interior SALLY JEWELL, Secretary
}

\section{U.S. Geological Survey Suzette M. Kimball, Acting Director}

\author{
U.S. Geological Survey, Reston, Virginia: 2013
}

For more information on the USGS - the Federal source for science about the Earth, its natural and living resources, natural hazards, and the environment, visit http://www.usgs.gov or call 1-888-ASK-USGS.

For an overview of USGS information products, including maps, imagery, and publications, visit http://www.usgs.gov/pubprod

To order this and other USGS information products, visit http://store.usgs.gov

Any use of trade, firm, or product names is for descriptive purposes only and does not imply endorsement by the U.S. Government.

Although this information product, for the most part, is in the public domain, it also may contain copyrighted materials as noted in the text. Permission to reproduce copyrighted items must be secured from the copyright owner.

Suggested citation:

Morrison, J.M., Kuffner, I.B., and Hickey, T.D., 2013, Methods for monitoring corals and crustose coralline algae to quantify in-situ calcification rates: U.S. Geological Survey Open-File Report 2013-1159, 11 p., http://pubs.usgs.gov/ of/2013/1159/. 


\section{Acknowledgments}

The development of this calcification monitoring network was principally funded by the U.S. Geological Survey (USGS) Coastal \& Marine Geology Program, with supplementary funds from the USGS Terrestrial, Freshwater, and Marine Ecosystems Program and grants from the USGS Global Change Research Fund and the Department of Interior Southeast Climate Science Center. For help in setting up and maintaining the calcification stations, we thank A. Brame, J. Sanford, C. Reich, C. Reynolds, and C. Williams. We thank K. Ludwig for engineering the tilesaw modifications and K. Hargrave for the illustration in figure 1. We thank C. Reich and C. Williams for their constructive comments on the manuscript.

We express our gratitude to the National Park Service and the Florida Keys National Marine Sanctuary for permitting the monitoring network under scientific permits DRT0-2009-SCI-0009, DRTO-2011-SCI-0004, BISC-2009-SCI-0019, BISC-2010-SCI-0035, BISC-2011-SCI-0025FKNMS2008-062A, and FKNMS-2010-122. 


\section{Contents}

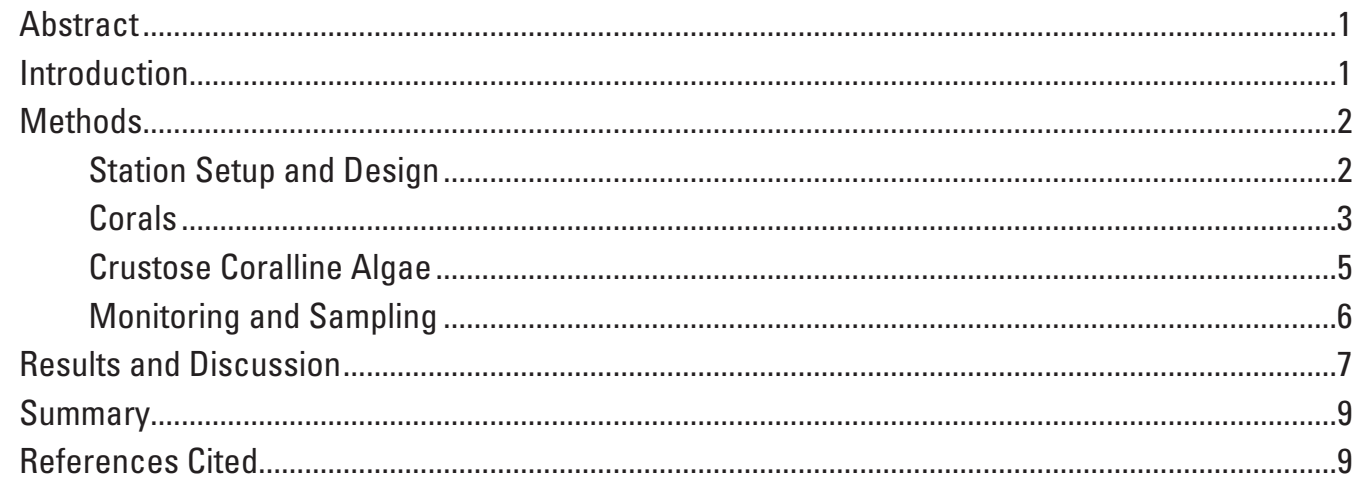

\section{Figures}

1. Exploded diagram of a coral and crustose coralline algal calcification station, including all fasteners and attachments ..........................................................................

2. Photographs showing mounting, staining, and weighing of coral colonies.....................4

3. Photographs showing monitoring and sampling methods .............................................6

4. Photographs showing plastic "pear" neck tags, used in the livestock industry, used here as algal recruitment tiles............................................................................

\section{Table}

1. Materials used to construct each calcification station. All fasteners were marinegrade stainless steel (alloy 316 ) 


\section{Conversion Factors}

Inch/Pound to SI

\begin{tabular}{|c|c|c|}
\hline Multiply & By & To obtain \\
\hline \multicolumn{3}{|c|}{ Length } \\
\hline inch (in.) & 2.54 & centimeter $(\mathrm{cm})$ \\
\hline inch (in.) & 25.4 & millimeter $(\mathrm{mm})$ \\
\hline foot $(\mathrm{ft})$ & 0.3048 & meter $(\mathrm{m})$ \\
\hline mile (mi) & 1.609 & kilometer (km) \\
\hline \multicolumn{3}{|c|}{ Volume } \\
\hline gallon (gal) & 3.785 & liter (L) \\
\hline
\end{tabular}

Temperature in degrees Celsius $\left({ }^{\circ} \mathrm{C}\right)$ may be converted to degrees Fahrenheit $\left({ }^{\circ} \mathrm{F}\right)$ as follows:

${ }^{\circ} \mathrm{F}=\left(1.8 x^{\circ} \mathrm{C}\right)+32$

Temperature in degrees Fahrenheit $\left({ }^{\circ} \mathrm{F}\right)$ may be converted to degrees Celsius $\left({ }^{\circ} \mathrm{C}\right)$ as follows:

${ }^{\circ} \mathrm{C}=\left({ }^{\circ} \mathrm{F}-32\right) / 1.8$ 



\title{
Methods for Monitoring Corals and Crustose Coralline Algae to Quantify In-Situ Calcification Rates
}

\author{
By Jennifer M. Morrison, Ilsa B. Kuffner, and T. Don Hickey
}

\section{Abstract}

The potential effect of global climate change on calcifying marine organisms, such as scleractinian (reef-building) corals, is becoming increasingly evident. Understanding the process of coral calcification and establishing baseline calcification rates are necessary to detect future changes in growth resulting from climate change or other stressors. Here we describe the methods used to establish a network of calcification-monitoring stations along the outer Florida Keys Reef Tract in 2009. In addition to detailing the initial setup and periodic monitoring of calcification stations, we discuss the utility and success of our design and offer suggestions for future deployments. Stations were designed such that whole coral colonies were securely attached to fixed apparati $(n=10$ at each site) on the seafloor but also could be easily removed and reattached as needed for periodic weighing. Corals were weighed every 6 months, using the buoyant weight technique, to determine calcification rates in situ. Sites were visited in May and November to obtain winter and summer rates, respectively, and identify seasonal patterns in calcification. Calcification rates of the crustose coralline algal community also were measured by affixing commercially available plastic tiles, deployed vertically, at each station. Colonization by invertebrates and fleshy algae on the tiles was low, indicating relative specificity for the crustose coralline algal community. We also describe a new, nonlethal technique for sampling the corals, used following the completion of the monitoring period, in which two slabs were obtained from the center of each colony. Sampled corals were reattached to the seafloor, and most corals had completely recovered within 6 months. The station design and sampling methods described herein provide an effective approach to assessing coral and crustose coralline algal calcification rates across time and space, offering the ability to quantify the potential effects of ocean warming and acidification on calcification processes.

\section{Introduction}

The calcium carbonate skeletons produced by scleractinian corals constitute the foundation of coral reef ecosystems, providing habitat and protection for a diverse array of marine organisms. Coral reefs also offer immeasurable value to humans through tourism, fisheries, and the protection of coasts from erosion. In the last few decades, corals have faced an increasing number of local, chronic stressors (such as disease, coastal development and sedimentation, eutrophication, and overfishing) as well as extreme temperature anomaly events, the effects of which are alarmingly apparent in declining coral populations worldwide (De'ath and others, 2012; Costa Jr. and others, 2008; Edinger and others, 1998; Fabricius, 2005; Gardner and others, 2003; Jackson and others, 2001; Reopanichkul and others, 2009; Hughes, 1994; Wolanski and others, 2009; Aronson and others, 2002; Berkelmans and Oliver, 1999; Eakin and others, 2010). Moving into the future, increased frequency and intensity of warm-water-induced bleaching events, associated with ocean warming, and decreased carbonate ion concentrations (ocean acidification) represent the two most critical long-term threats to coral reefs (Hoegh-Guldberg, 1999; Hoegh-Guldberg and others, 2007).

Reef-building corals are especially susceptible to ocean warming and acidification because of the narrow water temperature range and high carbonate ion concentration needed for optimal skeletal production (Cantin and others, 2010; Carricart-Ganivet, 2004; Kleypas and Langdon, 2006; Hughes and others, 2003; Veron and others, 2009; Andersson and Gledhill, 2013; De'ath and others, 2009). It is necessary to document current patterns in calcification to detect and quantify future changes, resulting from natural or anthropogenic stressors. Estimates of calcification rates of individual coral colonies are most commonly obtained through measurements of skeletal extension rates. To determine linear extension, cores are collected from live corals, sliced parallel to the main growth axis, and x-rayed (Knutson and others, 1972; Hudson, 1981). The distance between adjacent high-density bands in the skeleton (annual linear extension), visible in the x-ray image, is measured and used to extrapolate the calcification rate by multiplying the linear extension rate by the average bulk skeletal density. There are several inherent limitations and issues with using this method, as demonstrated by the large amount of variability in the extension rates reported in such studies (Carricart-Ganivet, 2011). Measuring calcification directly, as opposed to calculating it using linear extension, may provide less variable data. In addition, direct measurements enable us 
to assess sub-annual patterns in calcification rates and make more direct inferences regarding the environmental variables driving calcification processes.

Whereas an abundance of studies have focused on establishing growth rates of reef-building corals, there are few studies reporting calcification rates of the crustose coralline algal (CCA) community. Though CCA may not calcify as quickly as reef-building corals (Adey and Vassar, 1975; Kuffner and others, 2013), their benthic cover far exceeds that of corals, in terms of geographical expanse and the amount of substratum covered in the photic zone (Steneck, 1986). Crustose coralline algae are ubiquitous on reefs and play a critical role in the development and stabilization/cementation of reef structures (Tierney and Johnson, 2012; Björk and others, 1995), the production of carbonate sediments (Adey and Macintyre, 1973), and the attraction of coral larvae and other invertebrates for settlement (Morse and others, 1988; Whalan and others, 2012). The importance of CCA, both ecologically and structurally, to coral reef ecosystems, is reason enough to merit further study. Furthermore, previous studies have demonstrated the vulnerability of CCA to simulated ocean acidification conditions (Kuffner and others, 2008; Hall-Spencer and others, 2008; Anthony and others, 2008), suggesting that monitoring CCA will become increasingly important in the future and could serve as an indicator of the effect and regional severity of ocean acidification.

This report discusses in detail the methods and materials used to construct and maintain a network of calcificationmonitoring stations along the outer Florida Keys Reef Tract (FKRT), which has proven successful in documenting spatial and temporal differences in coral and CCA calcification rates (Kuffner and others, 2013). This monitoring network is the first of its kind to systematically measure in-situ calcification rates of whole coral colonies and CCA in a reef-crest environment. Corals were monitored over a 2-year period, during which time they were removed for weighing every 6 months. Algal recruitment tiles were deployed every 6 months to measure net CCA accretion. We also introduce in this report a nonlethal method of sampling coral colonies, which provides a permanent, whole-colony growth record of the corals for additional analyses (such as measurements of linear extension, bio-erosion, stable isotopes, and trace elements) and preserves the remaining live coral for placement back on the reef.

\section{Methods}

\section{Station Setup and Design}

Stations were designed specifically for the purpose of regular, long-term (multi-year) monitoring of coral and CCA calcification rates. We chose to use small, intact colonies of coral rather than nubbins or fragments (Cook and others, 2002), to capture growth true to whole-colony morphology. We also used independent blocks instead of racks for mounting the corals, for the sake of statistical power (each block represented a statistically independent replicate). This study was further set apart from other in-situ calcification studies by the fact that, rather than studying coral growth at more accessible, inshore sites to infer growth at offshore reefs, monitoring took place at sites along the outer reef tract. Specific criteria for site selection included habitat type (spur-and-groove or low-relief hard bottom), depth (12 to 18 feet), and the availability of oceanographic and meteorological data. For the first round of monitoring, we chose to study the massive, reef-building coral Siderastrea siderea because of its relative abundance along the FKRT and its resilience (Muthiga and Szmant, 1987; Lirman and Fong, 2007; Colella and others, 2012). The station design and monitoring methodology, however, could easily accommodate small colonies of any coral species.

A single station consisted of an $8 \times 8 \times 8$-inch concrete block ("half block") with a small, whole coral colony and an algal recruitment tile attached (fig. 1). We used concrete blocks as the basis of the calcification stations because they are commercially available everywhere and are not susceptible to corrosion. Marine-grade stainless steel (alloy 316) hardware was used because of its corrosion resistance, and all fasteners were of the same alloy to prevent electrolytic corrosion. All fasteners had a $1 / 4$-inch screw diameter and 20 threads per inch ("1 $1 / 4-20 ")$. Prior to installation, a single, approximately $1 / 4$-inch hole (slightly larger than the cap screw diameter for easy removal of the coral for weighing) was drilled into the top-facing side of each concrete block for mounting the coral colony; two $1 / 4$-inch holes were drilled diagonally across the bottom-facing side of the block, roughly 4 inches apart, to allow the block to be secured to the substratum; and two $1 / 4$-inch holes were drilled on one side of the block, approximately 1 inch apart, for mounting the algal recruitment apparatus (see fig. 1 for approximate hole locations). Stations were installed in areas of low-relief, hard-bottom habitat, where other corals were presently growing and where there was relatively flat, secure substratum available for block installation.

To install each station, two holes, spaced roughly 4 inches apart [using a template made of polyvinyl chloride (PVC) sheeting], were drilled 2 to 3 inches deep into the substratum using a pneumatic drill (with a $1 / 2$-inch masonry bit), powered by an air compressor located onboard a two-point-anchored vessel. The substratum surrounding the holes was then scraped with a rock chisel (to flatten the surface and remove turf algae) and brushed with a plastic, stiff-bristled brush (to remove sediment and other loose material), to ensure maximum adhesion of the epoxy to the seafloor. The holes were filled with All-Fix underwater epoxy (Cir-Cut Corporation, Philadelphia, Pennsylvania, U.S.A.), and a 6-inch-long threaded rod was inserted in each epoxy-filled hole, with care not to get any epoxy in the threads on the upper half of the rod. Additional epoxy was mounded around the base of the rods and on the substratum in between, to provide further support and adhesion for the rods and blocks, respectively. As soon as each pair of rods was in place (while the epoxy was still wet), the concrete block was 


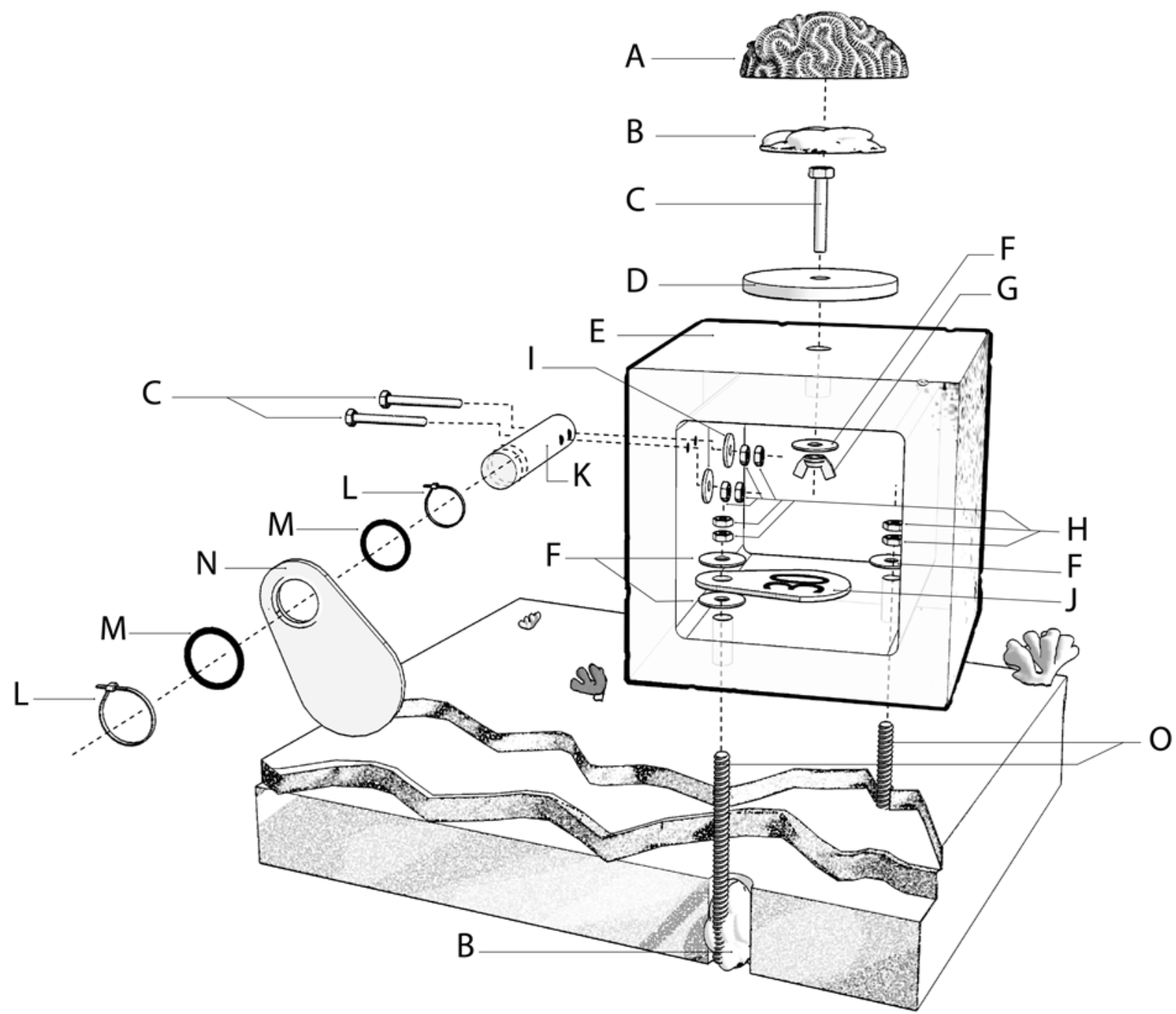

Figure 1. Exploded diagram of a coral and crustose coralline algal calcification station, including all fasteners and attachments. Labels correspond with those listed in table 1.

lowered onto the rods (by lining up the holes on the bottom of the block) carefully, so as not to disturb the newly epoxied rods. Once the block was set, epoxy was added underneath the sides of the block as needed, to further stabilize the block on uneven substratum. Ten stations were installed at each site, spaced roughly 6 to 12 feet from each other.

\section{Corals}

While the epoxy cured, coral colonies were collected from a nearby site of similar depth and habitat type (Kuffner and others, 2013). Colonies were chosen that were hemispherically shaped (as opposed to encrusting), within the target size range (3- to 4-inch diameter), and lacking any visible signs of disease or clionid sponge infestation. Selected corals were removed from the reef by hammering (with a mallet) a rock chisel around the bottom of the colony. Once free from the substratum, a hammer and chisel were used to flatten the underside of the coral (if needed) and a wire brush was used to remove any loose debris, algae, or invertebrates. Epoxy was spread onto the bottom (chiseled side) of the coral, using excess putty to fill in any holes or crevices. The coral was then positioned on a round, gray PVC disc (3- or 4-inch diameter, depending on the size of the coral) that was roughened on one side with sandpaper and had a 1/4-inch hole drilled in the center and a 3-inch-long hex head cap screw placed in the hole (figs. 1 and $2 A$ ). The coral and roughened side of the disc were pushed together firmly to create a strong seal (fig. $2 A$ ). A unique, three-digit number was pre-etched onto the bottom side of each disc and was used to identify the corals throughout the study.

Once the coral colonies were collected and mounted onto PVC discs ( $\mathrm{n}=10$ for each site), they were transported back to the dock to be weighed and stained. Ten 5-gallon buckets were modified, prior to the first installation trip, for transporting and staining the corals. Each bucket was fitted with a plastic flower 

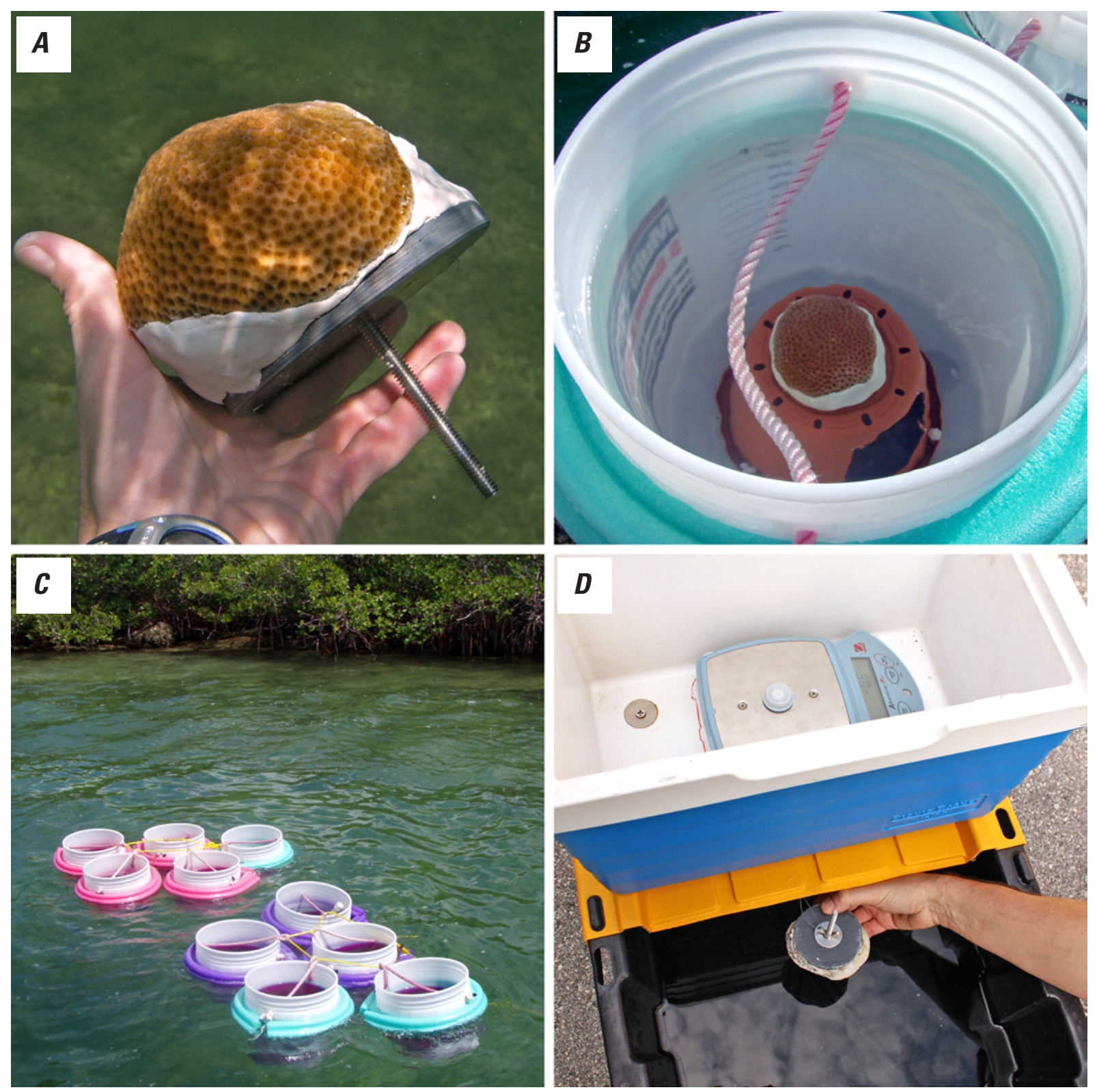

Figure 2. Mounting, staining, and weighing of coral colonies. $A$, Coral colony epoxied to the plastic disc and cap screw. $B$, Coral colony in a transport bucket. $C$, Coral colonies being stained with alizarin red $S$. $D$, Coral colony being weighed using an under-loading balance.

pot that had a $1 / 4$-inch hole drilled in the bottom, three $1 / 4$-inch holes drilled into the outer rim, and a roughly 4 -inch hole cut out of the side. The outer rim of the flower pot was attached to the bottom of each bucket using nylon $1 / 4-20$ bolts, inserted through $1 / 4$-inch holes that were drilled into the bucket and the holes in the rim of the pot and secured with nylon $1 / 4-20$ hex nuts (fig. $2 B$ ). The flower pot and bolt connections were reinforced with hot glue. The buckets were then filled with seawater, and collected coral colonies were placed in the buckets, with the attached cap screw positioned through the $1 / 4$-inch hole in the bottom of the flower pot, securing the coral in an upright position (fig. $2 B$ ). To prevent heat stress in the corals while they were on the boat, the temperature of the water in the buckets was closely monitored so that it did not exceed $30^{\circ} \mathrm{C}$. If the temperature neared this threshold, a shade cover was laid over the buckets and, if necessary, cool seawater was added.

At the dock, pre-weighed aliquots of alizarin red $\mathrm{S}$ $(15 \mathrm{mg} / \mathrm{L})$ were added to the seawater in each transport bucket. The corals were kept in the dye for 4 hours during the period surrounding the solar zenith (approximately $11 \mathrm{AM}$ to 3 PM Eastern Daylight Time), maximizing the incorporation of the stain into the coral skeleton. Staining the surface of the coral skeleton provided a time stamp for use in later growth measurements. For the duration of the staining period, the buckets were suspended in the ocean by buoyant rings (swim 
noodles), secured around the rim of each bucket, to maintain ambient seawater temperature inside the buckets (fig. 2C).

During the staining period, corals also were weighed using the buoyant weight technique (Jokiel and others, 1978). The weighing apparatus consisted of a heavy duty plastic bin, filled to a mark (at about $2 / 3$ full) with seawater, and a plastic cooler, attached to the top of one half of the lid (fig. 2D). A battery-operated balance with an under-loading hook was placed inside the cooler, and a braided MicroDyneema FireLine ${ }^{\circledR}$ fishing line (Berkley ${ }^{\circledR}$, Spirit Lake, Iowa, U.S.A.) was hung with a slip knot from the balance hook and the line passed through aligning 1-inch holes that had been cut through the bottom of the cooler and the plastic bin lid. A stainless steel washer was tied to the other end of the line so the corals could be attached for weighing. With the balance zeroed, the cap screw on the bottom of the coral was slid through the hole in the washer. The coral was gently lowered into the seawater in the bin until the line was taut (the weight of the coral provided enough tension between the threaded rod and the vertical washer to hold the coral in place without a fastener), making sure the coral was not resting on the bottom of the bin. The other one-half of the lid was then placed on the bin to minimize wind movement over the water, the balance was allowed time to settle, and the weight was recorded for each coral. The "bird's eye" length and width dimensions were measured with calipers and used to calculate the planar surface area of the coral (using the formula for the area of an ellipse). The presence of any boring organisms on the surface of the colony also was noted before returning it to the transport bucket. The change in buoyant mass between weighing intervals was converted to dry mass, using a seawater density of $1.02 \mathrm{~g} / \mathrm{cm}^{3}$ and an aragonite density of $2.93 \mathrm{~g} / \mathrm{cm}^{3}$ (see Jokiel and others, 1978 for conversion equations), and normalized to the 2-dimensional surface area of each coral.

When the epoxy had finished curing (at least 24 hours later) and the rods were firmly embedded in the reef, the concrete blocks were fastened down using a fender washer and two machine screw hex nuts on each rod (fig. 1, table 1). An identifying tag, with the station number (different from the coral number), was fixed between two washers on one of the rods (fig. 1, table 1). With the block secured to the substratum, the coral was then mounted to the block by inserting the attached cap screw through the hole in the top of the block and fastening it with a fender washer and wing nut (figs. 1 and $3 \mathrm{~A}$, table 1). This allowed for secure attachment of the coral to the block as well as the ability to remove the coral easily for periodic weighing and staining.

\section{Crustose Coralline Algae}

To measure accretion rates of the CCA community, algal recruitment tiles were attached, in a vertical position, to the side of each block (fig. $3 A$ ). The recruitment tile, a white nylon "pear" livestock neck tag (National Band and Tag Co., Newport, Kentucky, U.S.A.), was fitted onto a 4-inch-long nylon rod with two pre-drilled $1 / 4$-inch holes in the side (fig. 1, table 1). Commercially available tiles (fig. $4 A$ ) were used for this study because they were relatively inexpensive, did not require any preparation or cutting, and did not necessitate dissolving the samples to obtain dry mass, thereby allowing for sample archival. Tiles were made from eight different manufacturing molds, marked clearly on each tag (fig. 4A). Because differences in pre-deployment tile weights were significant between molds but negligible within each mold (for a single

Table 1. Materials used to construct each calcification station. All fasteners were marine-grade stainless steel (alloy 316).

[Dimension abbreviations: diam, diameter; in, inches; cm, centimeters; tpi, threads per inch; lg, length; mm, millimeters; p, pitch (distance between threads); t, thickness; w, width; ht, height; id, inner diameter; od, outer diameter]

\begin{tabular}{|c|c|c|c|c|}
\hline Label & Description & Quantity & Standard size & Approximate metric equivalent \\
\hline A & Whole coral colony & 1 & $3-4$ in (diam) & $7.5-10 \mathrm{~cm}($ diam $)$ \\
\hline B & Underwater epoxy & & & \\
\hline $\mathrm{D}$ & Gray polyvinyl chloride (PVC) disc & 1 & 3 or 4 in $($ diam $) \times 7 / 16$ in $(t)$ & 7.5 or $10 \mathrm{~cm}($ diam $) \times 11 \mathrm{~mm}(\mathrm{t})$ \\
\hline $\mathrm{E}$ & Concrete block ("half block") & 1 & $8(\lg ) \times 8(\mathrm{w}) \times 8$ in (ht) & $20(\lg ) \times 20(\mathrm{w}) \times 20 \mathrm{~cm}(\mathrm{ht})$ \\
\hline G & Wing nut & 1 & $1 / 4$ in (id) -20 (tpi) & $6 \mathrm{~mm}$ (id) x $1 \mathrm{~mm}(\mathrm{p})$ \\
\hline $\mathrm{H}$ & Machine screw hex nut & 8 & $1 / 4$ in (id) -20 (tpi) & 6 mm (id) x 1 mm (p) \\
\hline I & Flat washer & 2 & $1 / 4$ in (id) $x 9 / 16$ in (od) & 6 mm (id) x 18 mm (od) \\
\hline $\mathrm{J}$ & Blue "pear" livestock tag with station number & 1 & $3 \frac{1}{2}$ in $(h t)$ & $9 \mathrm{~cm}(\mathrm{ht})$ \\
\hline $\mathrm{K}$ & White nylon rod & 1 & $7 / 8$ in $($ diam $) \times 4$ in $(\mathrm{lg})$ & $22 \mathrm{~mm}$ (diam) x $10 \mathrm{~cm}(\mathrm{lg})$ \\
\hline $\mathrm{O}$ & Threaded rod & 2 & $1 / 4$ in $($ diam $)-20$ (tpi) x 6 in $(\lg )$ & $6 \mathrm{~mm}(\operatorname{diam}) \times 1 \mathrm{~mm}(\mathrm{p}) \times 15 \mathrm{~cm}(\mathrm{lg})$ \\
\hline
\end{tabular}



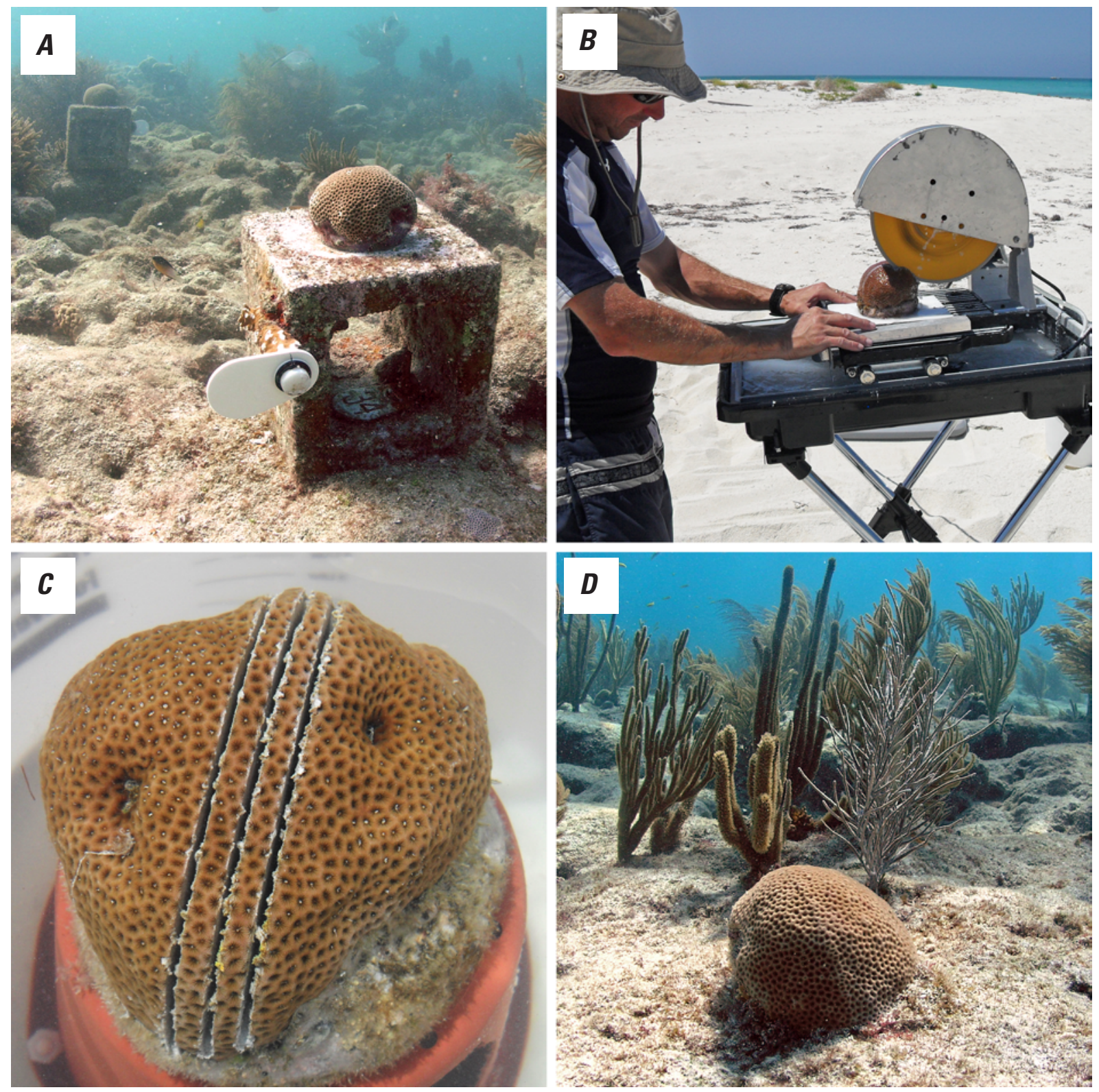

Figure 3. Monitoring and sampling methods. $A$, Calcification station in the field (note second station in the background). $B$, Slabbing live coral colonies with a modified tile saw. $C$, Coral colony after it has been sliced. $D$, Healed coral colony, 6 months post-sampling.

batch of tiles), it was not necessary to pre-weigh each tile as long as the mold number was noted. The whole assembly was affixed to the side of the block by sliding two 3-inch hex head cap screws through the holes in the nylon rod and the block and securing it in place with a flat washer and two machine screw hex nuts on each cap screw (fig. 1, table 1). The tile was oriented vertically, to more selectively target the CCA (as opposed to the fouling) community, and to the side (away from the block), to allow grazing organisms equal access to both sides of the tile (fig. 3A). The tile was held in place on the nylon rod and in the correct orientation by a rubber O-ring and 4-inch "miniature" cable tie on each side (fig. 1, table 1).

\section{Monitoring and Sampling}

Following the initial setup of the calcification stations, sites were revisited every 6 months [late spring (May) and late fall (November)] to weigh the corals, allowing us to record precise changes in mass gained per unit time and detect any sub-annual patterns in calcification rates. Corals were only stained during springtime visits. Weighing and staining were completed in the same manner as in the initial collection, except that, during fall (nonstaining) visits, transport buckets remained in the boat while corals were weighed on the dock, since the corals were out of the ocean for a much shorter duration than during springtime (staining) visits. The algal 

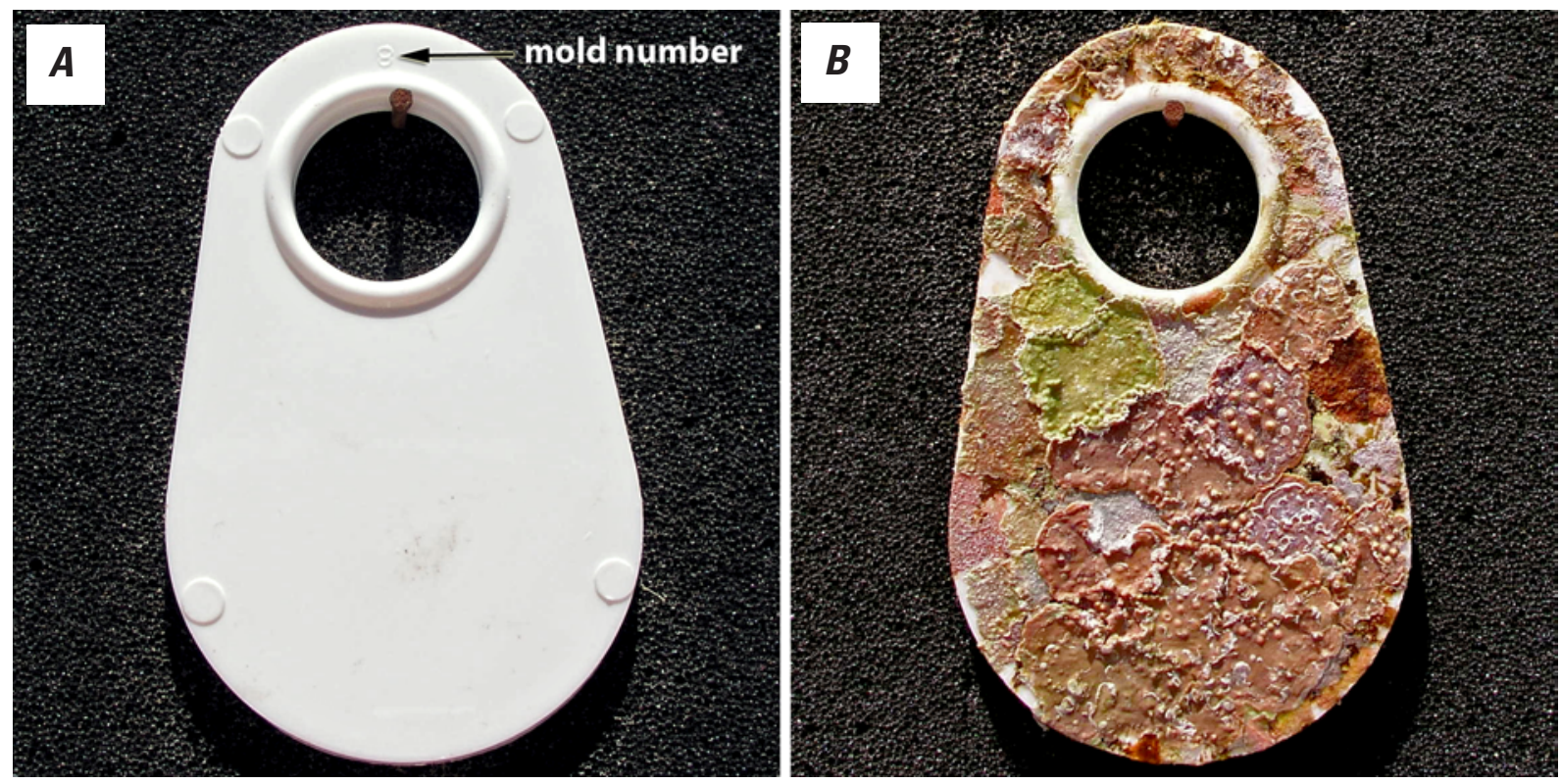

Figure 4. Plastic "pear" neck tags, used in the livestock industry, used here as algal recruitment tiles. $A$, Blank (predeployment) tile, with the manufacturing mold number clearly marked. $B$, Post-deployment tile, completely encrusted by crustose coralline algae after 6 months.

recruitment tiles also were collected at each visit and replaced with new tiles. Harvested tiles were kept in individual, sealable plastic bags and stored on ice or refrigerated $\left(4^{\circ} \mathrm{C}\right)$ until they could be processed in the lab. Before reattaching the corals and new algal tiles to the blocks, the top of each block was cleaned with a rock chisel and brush, and the front portion of each nylon rod was scraped clean with a wood chisel. The station number plates and coral cap screws also were cleaned during each visit. Unless it was the final visit of the monitoring period, corals were then returned to the study site and attached to new blocks at random.

At the completion of the monitoring period (corals in this study were monitored for 2 years), the corals were removed from the calcification stations, and two slabs (roughly $3 / 16$ inch, or 5 millimeters, thick) were cut from the middle of each colony using a modified wet tile saw in the field, with seawater in the cooling bath (figs. $3 B, C$ ). To hold the coral in place while slicing, the coral was secured to a piece of PVC sheeting by inserting the cap screw through a hole drilled in the center and fastening it with a wingnut. To position the saw blade for the first cut, plastic spacers (approximately $5 / 16$ inch thick) were placed between the PVC sheet and the edge of the saw-blade guide, and a single spacer was removed after each cut so that the thickness of the slabs was as consistent as possible. Using a hand-held band saw, the coral was then separated from the PVC plate, freeing the two newly cut slabs. The remaining live halves of the coral were kept together, and all 10 corals from each site were then returned to a location near their collection site. Once appropriate locations for the corals were identified, the substratum was scraped clean with a rock chisel and brush, and the corals were reattached to the seafloor using epoxy. Harvested slabs were cleaned with a sonicator in a distilled water bath, air dried, and photographed with a stereomicroscope in the lab. The distance from the alizarin red stain line to the surface of the coral was measured along the corallite wall for each slab, to obtain estimates of linear extension rates, using iSolutions ${ }^{\circledR}$ image analysis software.

In preparation for weighing, algal tiles were rinsed with fresh water to remove loose sediments (though gently, so as not to detach any CCA or invertebrates), photographed on both sides, and dried in a $60{ }^{\circ} \mathrm{C}$ oven for 48 hours (fig. $4 B$ ). Once dry, tiles were weighed with and without attached invertebrates. Any pieces of CCA that did flake off during the rinsing or drying process were included in the weight of the tile. The mold-specific mean dry weight was then subtracted from the 48-hour (post-deployment) dry weight to obtain the mass [grams of calcium carbonate $\left(\mathrm{CaCO}_{3}\right)$ ] gained during the 6-month deployment period. The number of parrotfish bite marks on each tile was counted, using the digital photographs of the tiles, to reveal any patterns in grazing pressure.

\section{Results and Discussion}

Our calcification station design, in combination with the methods employed to measure growth, proved effective for monitoring in-situ coral and crustose coralline algal (CCA) calcification rates (see Kuffner and others, 2013 for detailed results). The station design successfully allowed for the secure attachment and periodic removal of coral colonies and algal tiles and ensured firm fixation of the blocks to the substratum. The majority of the stations have remained intact and in place, 
with the exception of a handful of blocks ( 5 of 40 blocks, in the first 4 years of the study) that became loose or, in some cases, completely detached from the seafloor as a result of strong storms or boats anchoring on the site. Dislodged blocks were reinstalled in their original (or, when not possible, a nearby) location by drilling and epoxying new rods in place. Loose blocks were reinforced using additional epoxy placed between the block and the substratum and around the fasteners. In one case, a large piece of reef substratum, which held one of the calcification stations, was flipped over during a high surf event from Hurricane Sandy, resulting in bleaching (caused by lack of light) of the attached coral colony. Corals have shown very little mortality while mounted to the calcification stations. To date, only 3 out of 80 colonies have been omitted from the dataset: 2 because of severe sponge infestations and 1 because it was removed from the study site by vandals. In fact, new polyps were often visible along the growth margins and within the colonies, and most corals grew new tissue over the epoxy at the base of the colony, attesting to their ability to survive transplantation and their general health throughout the monitoring period. Little change was observed in the infaunal community (visible from the outside of the corals) during the study, indicating that corals were no more or less susceptible to infestation while attached to the blocks.

Corals were weighed in November and May to establish summer growth rates (measured in November) and winter growth rates (measured in May), and rates were subsequently compared to elucidate any seasonal patterns in calcification. Since we aligned the growth intervals with seasonal boundaries, the weighing intervals used in this study would be applicable worldwide (seasons would simply be reversed in the southern hemisphere), enabling the synchronization of calcification-monitoring efforts and the evaluation of spatial patterns on a much broader scale. Originally we intended to stain the corals during each visit (every 6 months), but, after harvesting the first batch of corals in Spring 2011, it was apparent that reduced calcification rates during the winter prevented corals from incorporating enough dye into their skeleton during the 4-hour staining period to produce a distinct band. Corals from the Dry Tortugas, where calcification rates were highest (Kuffner and others, 2013), were the only ones in which these winter stain lines were clearly visible. Thus, we only stained our second batch of corals during springtime visits.

Algal recruitment tiles were deployed at every station to measure net CCA accretion (it was not possible to measure gross accumulation, as tiles were exposed to grazing). Because using nylon tags of known weight and surface area removes the need for sample dissolution, samples can be archived and used for additional analyses (for example, CCA species identification for community composition analyses). Only 2 of the 200 tiles deployed to date have disappeared from the stations during their 6-month deployment. The proportional contribution of attached invertebrates to the total weight accrued on each tile was minimal (mean $\pm \mathrm{SE}=3.29$ plus or minus 0.6 percent) and was only noticeable on a small number of tiles ( 82 percent of the tiles had less than 5 percent invertebrate weight), indicating that the algal tiles were successful in attracting predominately the CCA community. Invertebrates that did settle on the tiles were easily removed for weighing (for example, bivalves, fire coral, and worms) or did not add a measurable amount of weight to necessitate removal (for instance, most sponges and bryozoans). Despite invertebrate mass being easy to exclude, competition for tile space would potentially be of concern since it has been shown that invertebrates, once settled, have the ability to out-compete slowergrowing CCA for space (Breitburg, 1984). However, instances of substantial coverage by these organisms were rare in this study; thus, the effect of competition for tile space on CCA growth was likely minimal. Spatial differences in CCA growth were observed (Kuffner and others, 2013), but the role of herbivory and territorial damselfish is unclear and needs to be investigated in future studies. Controlling for grazing will be necessary to quantify its effect on CCA growth.

Harvest of coral slabs from live colonies in the field, prior to reattaching them to the reef, offers a nonlethal method of obtaining a complete-colony record of growth, which provides an invaluable tool for further studies. Of the sampled colonies revisited (30 out of 40), 100 percent survival was attained, and the two halves of each coral colony had fused together within 6 months after harvesting, leaving only a faint, raised seam line where the two halves joined (fig. $3 D$ ). We found that colonies in which the two halves were not epoxied together prior to attachment to the seafloor healed more quickly than those that had epoxy between the halves, suggesting that direct contact of coral tissue from the two halves promoted the healing process. In addition to linear extension measurements, numerous other studies can be performed using the coral slabs, to further investigate growth parameters and environmental variation over the course of skeletal formation. For example, corallite morphology (including corallite diameter and spacing) has been shown to vary in response to environmental conditions, such as light intensity or sedimentation rate (Foster, 1979; Foster, 1980). Such morphological characteristics can be assessed within coral slabs to analyze phenotypic patterns and attempt to connect them with underlying environmental factors. The area of coral skeleton excavated by bio-eroding organisms also can be approximated using digital x-rays of the slabs, and inferences can be made regarding water quality and water-column productivity based on bio-erosion data (Sammarco and Risk, 1990). The relative concentrations of strontium and calcium $(\mathrm{Sr} / \mathrm{Ca})$ can be measured, using skeletal material from the slabs, and used, in conjunction with underwater temperature data, to calibrate this temperature proxy and reconstruct historical water temperatures (Beck and others, 1992) back to the date of coral colony establishment (in this case, nearly a decade). Carbonate material from the slabs also could potentially be analyzed for the purpose of calibrating other trace-element (such as boron and barium) or stableisotope (such as $\delta^{18} \mathrm{O}$ ) proxies for various environmental variables. 


\section{Summary}

Systematic, long-term monitoring to document current spatial and temporal patterns in coral and CCA calcification rates will be critical to detecting future changes and assessing the effects of ocean warming and acidification on calcification and reef-building processes. This study introduces a reliable and reproducible method for monitoring calcification rates of whole coral colonies and the CCA community. Our goal in presenting this guide is to encourage other programs to initiate long-term calcification monitoring and to provide specific methods to do so, in hopes of improving and synchronizing monitoring efforts and enabling the comparison of calcification rates across regions and oceans. A broad, collaborative calcification-monitoring effort would be instrumental in effectively documenting and quantifying the effects of global climate change on coral and algal carbonate deposition and reef construction.

\section{References Cited}

Adey, W.H., and Macintyre, I.G., 1973, Crustose coralline algae-A re-evaluation in the geological sciences: Bulletin of the Geological Society of America, v. 84, p. 883-904.

Adey, W.H., and Vassar, M., 1975, Colonization, succession and growth rates of tropical crustose coralline algae: Phycologia, v. 14, p. 55-69.

Andersson, A.J., and Gledhill, D., 2013, Ocean acidification and coral reefs-Effects on breakdown, dissolution, and net ecosystem calcification: Annual Review of Marine Science, v. 5, p. 321-348.

Anthony, K.R.N., Kline, D.I., Diaz-Pulido, G., Dove, S., and Hoegh-Guldberg, O., 2008, Ocean acidification causes bleaching and productivity loss in coral reef builders: Proceedings of the National Academy of Sciences of the United States of America, v. 105, p. 17442-17446.

Aronson, R.B., Precht, W.F., Toscano, M.A., and Koltes, K.H., 2002, The 1998 bleaching event and its aftermath on a coral reef in Belize: Marine Biology, v. 141, p. 435-447.

Beck, J.W., Edwards, R.L., Ito, E., Taylor, F.W., Recy, J., Rougerie, F., Joannot, P., Henin, C., 1992, Sea-surface temperature from coral skeletal strontium/calcium ratios: Science, v. 257, p. 644-647.

Berkelmans, R., and Oliver, J.K., 1999, Large-scale bleaching of corals on the Great Barrier Reef: Coral Reefs, v. 18, p. 55-60.
Björk, M., Mohammed, S.M., Björklund, M., and Semesi, A., 1995, Coralline algae, important coral-reef builders threatened by pollution: Ambio, v. 24, p. 502-505.

Breitburg, D.L., 1984, Residual effects of grazing - Inhibition of competitor recruitment by encrusting coralline algae: Ecology, v. 65, p. 1136-1143.

Cantin, N.E., Cohen, A.L., Karnauskas, K.B., Tarrant, A.M., and McCorkle, D.C., 2010, Ocean warming slows coral growth in the Central Red Sea: Science, v. 329, p. 322-325.

Carricart-Ganivet, J.P., 2004, Sea surface temperature and the growth of the West Atlantic reef-building coral Montastraea annularis: Journal of Experimental Marine Biology and Ecology, v. 302, p. 249-260.

Carricart-Ganivet, J.P., 2011, Coral skeletal extension rateAn environmental signal or a subject to inaccuracies?: Journal of Experimental Marine Biology and Ecology, v. 405 , p. $73-79$.

Colella, M.A., Ruzicka, R.R., Kidney, J.A., Morrison, J.M., and Brinkhuis, V.B., 2012, Cold-water event of January 2010 results in catastrophic benthic mortality on patch reefs in the Florida Keys: Coral Reefs, v. 31, p. 621-632.

Cook, C.B., Mueller, E.M., Ferrier, M.D., and Annis, E., 2002, The influence of nearshore waters on corals of the Florida Reef Tract, in Porter, J.W., and Porter, K.G., eds., The Everglades, Florida Bay, and Coral Reefs of the Florida Keys: An Ecosystem Sourcebook, Boca Raton, FL, CRC Press, p. 771-788.

Costa Jr., O.S., Nimmo, M., and Attrill, M.J., 2008, Coastal nutrification in Brazil-A review of the role of nutrient excess on coral reef demise: Journal of South American Earth Sciences, v. 25, p. 257-270.

De'ath, G., Fabricius, K.E., Sweatman, H., and Puotinen, M., 2012, The 27-year decline of coral cover on the Great Barrier Reef and its causes: Proceedings of the National Academy of Sciences of the United States of America, v. 109, p. 17995-17999.

De'ath, G., Lough, J.M., and Fabricius, K.E., 2009, Declining coral calcification on the Great Barrier Reef: Science, v. 323 , p. $116-119$. 
Eakin, C.M., Morgan, J.A., Heron, S.F., Smith, T.B., Liu, G., Alvarez-Filip, L., Baca, B., Bartels, E., Bastidas, C., Bouchon, C., Brandt, M., Bruckner, A.W., BunkleyWilliams, L., Cameron, A., Causey, B.D., Chiappone, M., Christensen, T.R.L., Crabbe, M.J.C., Day, O., de la Guardia, E., Díaz-Pulido, G., DiResta, D., Gil-Agudelo, D.L., Gilliam, D.S., Ginsburg, R.N., Gore, S., Guzmán, H.M., Hendee, J.C., Hernández-Delgado, E.A., Husain, E., Jeffrey, C.F.G., Jones, R.J., Jordán-Dahlgren, E., Kaufman, L.S., Kline, D.I., Kramer, P.A., Lang, J.C., Lirman, D., Mallela, J., Manfrino, C., Maréchal, J., Marks, K., Mihaly, J., Miller, W.J., Mueller, E.M., Muller, E.M., Orozco Toro, C.A., Oxenford, H.A., Ponce-Taylor, D., Quinn, N., Ritchie, K.B., Rodríguez, S., Rodríguez Ramírez, A., Romano, S., Samhouri, J.F., Sánchez, J.A., Schmahl, G.P., Shank, B.V., Skirving, W.J., Steiner, S.C.C., Villamizar, E., Walsh, S.M., Walter, C., Weil, E., Williams, E.H., Woody Roberson, K., and Yusuf, Y., 2010, Caribbean corals in crisis-Record thermal stress, bleaching, and mortality in 2005: PLOS ONE, v. 5, p. e13969.

Edinger, E.N., Jompa, J., Limmon, G.V., Widjatmoko, W., and Risk, M.J., 1998, Reef degradation and coral biodiversity in Indonesia-Effects of land-based pollution, destructive fishing practices and changes over time: Marine Pollution Bulletin, v. 36, p. 617-630.

Fabricius, K.E., 2005, Effects of terrestrial runoff on the ecology of corals and coral reefs-Review and synthesis: Marine Pollution Bulletin, v. 50, p. 125-146.

Foster, A.B., 1979, Phenotypic plasticity in the reef corals Montastraea annularis and Siderastrea siderea: Journal of Experimental Marine Biology and Ecology, v. 39, p. 25-54.

Foster, A.B., 1980, Environmental variation in skeletal morphology within the Caribbean reef corals Montastraea annularis and Siderastrea siderea: Bulletin of Marine Science, v. 30, p. 678-709.

Gardner, T.A., Cote, I.M., Gill, J.A., Grant, A., and Watkinson, A.R., 2003, Long-term region-wide declines in Caribbean corals: Science, v. 301, p. 958-960.

Hall-Spencer, J.M., Rodolfo-Metalpa, R., Martin, S., Ransome, E., Fine, M., Turner, S.M., Rowley, S.J., Tedesco, D., and Buia, M.C., 2008, Volcanic carbon dioxide vents show ecosystem effects of ocean acidification: Nature, v. 454, p. 96-99.

Hoegh-Guldberg, O., 1999, Climate change, coral bleaching and the future of the world's coral reefs: Marine and Freshwater Research, v. 50, p. 839-866.
Hoegh-Guldberg, O., Mumby, P.J., Hooten, A.J., Steneck, R.S., Greenfield, P., Gomez, E., Harvell, C.D., Sale, P.F., Edwards, A.J., Caldeira, K., Knowlton, N., Eakin, C.M., Iglesias-Prieto, R., Muthiga, N., Bradbury, R.H., Dubi, A., and Hatziolos, M.E., 2007, Coral reefs under rapid climate change and ocean acidification: Science, v. 318, p. 1737-1742.

Hudson, J.H., 1981, Growth rates in Montastraea annularisA record of environmental change in Key Largo Coral Reef Marine Sanctuary, Florida: Bulletin of Marine Science, v. 31, p. $444-459$.

Hughes, T.P., 1994, Catastrophes, phase shifts, and large-scale degradation of a Caribbean coral reef: Science, v. 265, p. 1547-1551.

Hughes, T.P., Baird, A.H., Bellwood, D.R., Card, M., Connolly, S.R., Folke, C., Grosberg, R., Hoegh-Guldberg, O., Jackson, J.B.C., Kleypas, J., Lough, J.M., Marshall, P., Nystrom, M., Palumbi, S.R., Pandolfi, J.M., Rosen, B., and Roughgarden, J., 2003, Climate change, human impacts, and the resilience of coral reefs: Science, v. 301, p. 929-933.

Jackson, J.B.C., Kirby, M.X., Berger, W.H., Bjorndal, K.A., Botsford, L.W., Bourque, B.J., Bradbury, R.H., Cooke, R., Erlandson, J., Estes, J.A., Hughes, T.P., Kidwell, S., Lange, C.B., Lenihan, H.S., Pandolfi, J.M., Peterson, C.H., Steneck, R.S., Tegner, M.J., and Warner, R.R., 2001, Historical overfishing and the recent collapse of coastal ecosystems: Science, v. 293, p. 629-638.

Jokiel, P.L., Maragos, J.E., and Franzisket, L., 1978, Coral growth-Buoyant weight technique, in Stoddart, D.R., and Johannes, R.E., eds., Coral reefs: research methods (monographs on oceanographic methodology), UNESCO, p. 529-541.

Kleypas, J.A., and Langdon, C., 2006, Coral reefs and changing seawater carbonate chemistry, in Phinney, J.T., HoeghGuldberg, O., Kleypas, J., Strong, A., and Skirving, W., eds., Coral reefs and climate change: science and management, Washington, DC, American Geophysical Union, p. 73-110.

Knutson, D.W., Buddemeier, R.W., and Smith, S.V., 1972 , Coral chronometers-Seasonal growth bands in reef corals: Science, v. 177, p. 270-272.

Kuffner, I.B., Andersson, A.J., Jokiel, P.L., Rodgers, K.S., and Mackenzie, F.T., 2008, Decreased abundance of crustose coralline algae due to ocean acidification: Nature Geoscience, v. 1, p. 114-117. 
Kuffner, I.B., Hickey, T.D., and Morrison, J.M., 2013, Calcification rates of the massive coral Siderastrea siderea and crustose coralline algae along the Florida Keys (USA) outer-reef tract: Coral Reefs, doi: 10.1007/s00338-013$1047-8$.

Lirman, D., and Fong, P., 2007, Is proximity to land-based sources of coral stressors an appropriate measure of risk to coral reefs? An example from the Florida Reef Tract: Marine Pollution Bulletin, v. 54, p. 779-791.

Morse, D.E., Hooker, N., Morse, A.N.C., and Jensen, R.A., 1988, Control of larval metamorphosis and recruitment in sympatric agariciid corals: Journal of Experimental Marine Biology and Ecology, v. 116, p. 193-217.

Muthiga, N.A., and Szmant, A.M., 1987, The effects of salinity stress on the rates of aerobic respiration and photosynthesis in the hermatypic coral Siderastrea siderea: Biological Bulletin, v. 173, p. 539-551.

Reopanichkul, P., Schlacher, T.A., Carter, R.W., and Worachananant, S., 2009, Sewage impacts coral reefs at multiple levels of ecological organization: Marine Pollution Bulletin, v. 58, p. $1356-1362$.

Sammarco, P.W., and Risk, M.J., 1990, Large-scale patterns in internal bioerosion of Porites - Cross continental shelf trends on the Great Barrier Reef: Marine Ecology Progress Series, v. 59, p. 145-156.
Steneck, R.S., 1986, The ecology of coralline algal crustsConvergent patterns and adaptative strategies: Annual Review of Ecology and Systematics, v. 17, p. 273-303.

Tierney, P.W., and Johnson, M.E., 2012, Stabilization role of crustose coralline algae during late Pleistocene reef development on Isla Cerralvo, Baja California Sur (Mexico): Journal of Coastal Research, v. 28, p. 244-254.

Veron, J.E.N., Hoegh-Guldberg, O., Lenton, T.M., Lough, J.M., Obura, D.O., Pearce-Kelly, P., Sheppard, C.R.C., Spalding, M., Stafford-Smith, M.G., and Rogers, A.D., 2009, The coral reef crisis-The critical importance of $<350 \mathrm{ppm} \mathrm{CO}_{2}$ : Marine Pollution Bulletin, v. 58, p. $1428-1436$.

Whalan, S., Webster, N.S., and Negri, A.P., 2012, Crustose coralline algae and a cnidarian neuropeptide trigger larval settlement in two coral reef sponges: PLOS ONE, v. 7 , p. e30386.

Wolanski, E., Martinez, J.A., and Richmond, R.H., 2009, Quantifying the impact of watershed urbanization on a coral reef-Maunalua Bay, Hawaii: Estuarine, Coastal and Shelf Science, v. 84, p. 259-268. 
For further information about this publication contact:

Director

U.S. Geological Survey

St. Petersburg Coastal and Marine Science Center

600 Fourth Street South

St. Petersburg, FL 33701

Or visit the St. Petersburg Coastal and Marine Science Center Web site at: http://coastal.er.usgs.gov/

Prepared by the Raleigh and the Rolla Publishing Science Center 



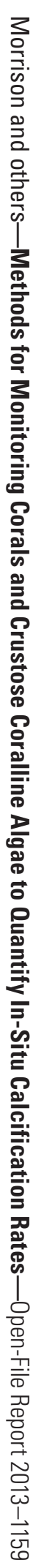

